\title{
Financial Component of Russia's Economic Safety Mechanism
}

\author{
Evaluation Model and Forecast
}

\author{
Goncharenko Liudmila / Professor, Dr in Economics \\ Director of Science and Research Institute "Innovative \\ Economy" \\ Plekhanov Russian University of Economics \\ Moscow, Russia \\ inn.invest@mail.ru
}

\author{
Sharko Elena / PhD in Economics \\ Researcher of Science and Research Institute "Innovative \\ Economy" \\ Plekhanov Russian University of Economics \\ Moscow, Russia \\ ersharko@yandex.ru
}

\author{
Sybachin Sergey / PhD in Economics \\ Leading Researcher of Science and Research Institute \\ "Innovative Economy" \\ Plekhanov Russian University of Economics \\ Moscow, Russia \\ sergeysyb@mail.ru
}

\author{
Khachaturyan Mikhail / PhD in Economics \\ Associate Professor of Management Theory and Business \\ Technologies Department \\ Plekhanov Russian University of Economics \\ Moscow, Russia \\ mike-hach@mail.ru
}

\author{
Gendon Angelica / PhD in Techniques \\ Associate Professor of Financial Control, Analysis and Audit Department \\ Plekhanov Russian University of Economics \\ Moscow, Russia \\ gendon1@yandex.ru
}

\begin{abstract}
In the most general sense, the safety of the state should be understood as the state's protection against negative impacts of a combination of social, economic, environmental and legal as well as internal and external coercive factors. At the same time, in terms of terminology, the economic safety of the state represents the ability of the state government to protect its own competitive potential against internal and external destabilizing factors in the international arena. Some scientists point out that the threat to the economic safety may be manifested as a decrease in the state's competitive status level, and suggest to consider it as a universal category that reflects the protection of the state from negative external and internal impacts, and also prompts the management system to respond quickly and eliminate various threats, which negatively affect the economic stability of the state.

Economic safety is a creating element of the economic stability shaping \& maintenance management structure, which is called upon to execute a number of functions, in particular, prediction, financial risk assessment, identification of threats, preservation of competitive advantages, and others. At the same time, it is regarded as a certain state of the state resources (capital, personnel, information, technique, technology, etc.) and entrepreneurial opportunities, whose existence guarantees the most effective use thereof in order to ensure stable functioning and dynamic scientific, technical and social development of the state as well as to prevent/respond to internal and external negative impacts (threats).
\end{abstract}

To evaluate the economic safety level, various methods and tools are available, some of them are very sophisticated for the use and require considerable time to process data for analysis, whilst the others relate to local methods, allowing only a fragmentary assessment of individual components of the state's economic safety. The search for new approaches to the identification and assessment of the financial component level of the economic safety has predefined the relevancy of this study; the results of the study can be implemented in practice both in the Russian economy and in the economy of any other country.

Keywords- economic safety; financial policy; financial component; budget deficit; national debt; export of goods and services; federal budget expenditures; economic profile.

\section{INTRODUCTION}

Economic safety is a sophisticated economic category that makes it possible to shape economic processes in a certain space and to identify development trends in real time mode. Undoubtedly, economic safety is a closed system that includes elements, incoming and outgoing flows, inter-system element interaction mechanisms and quantitative and qualitative characteristics of the status of these elements.

Depending on the scale of assessment, the following economic safety levels may be considered $[8 ; 9]$ : 
1) national economic safety: state economy status indicators stay at the level, showing that all economic processes function at a maximum efficiency, and the state balance is in surplus, allowing the resource potential to be expanded and opportunities for further sustainable development to be created;

2) regional economic safety: economic status indicators of a certain region stay at the level that shows that all economic processes function within the limits, established at the state level, and ensure an efficient use of the regional potential;

3) economic safety of an enterprise: economic status indicators of a business entity stay at the level that ensures normal completion of all business processes, and the results of these business activities are useful for the society and make a common contribution to the regional and national economy development;

4) economic safety of a person: this is a combination of all socio-economic factors of the life activity of each person (material and social benefits provided by the state to each citizen).

Despite the analytical levels, the economic safety, in the context of the sustainable development theory, means the possibility of obtaining a theoretical Gaussian oscillation nature for the asymmetric Poisson distribution, by means of which an equitable distribution of revenues at a simultaneous efficient allocation of the resources can be achieved.

Given there have been economic development trends of the Russian and world's economic systems in recent years, economic safety with its fundamental financial safety component should undoubtedly become the most critical concept and concern for the organizational and economic mechanism of the strategic economic safety management. Obviously, issues related to the economic safety assurance are a key challenge of the present time both in theory and in practice, which will require an extensive analysis and development of a responsible state policy, in particular, in the field of economy [13]. It is important to note that, on the one hand, the economic sciences more or less accurately and in detail explains and individual behaviors and economic events after they have already occurred, and, on the other hand, empirical and methodological economic forecasting is flawed, and often there is no reliable scientific basis, specifically in programming expected results of the state policy in one or another field $[7 ; 11]$

\section{MethodOLOGY}

Modern economy of the state is a very complex system, whose status is characterized by a large number of indicators. According to researchers, more than 300 indicators are available today; however, the research center of the Institute of Economics of the Russian Academy of Sciences identified 150 indicators (indexes) which allow describing almost all aspects of the state's economic system at the macro- and micro levels. Then, only 19 indicators, reflecting the most important aspects of the economic safety, were used to analyze and forecast threats. But for the economic safety of the state, limit values of the indicators, rather than the indicators themselves, are critical. Limit values of the economic safety mean those limiting values, whose overrun threatens with the fall of the national economy of the state [1; $12]$.

A list of limit values can include a large number of quantitative indicators, which nevertheless embed different content and calculation methods. The indicative analysis allows the identification of maximum deviations in the economic development parameters of regions and the state as a whole, in individual industries and business activities; having applied suitable limit values, threat may be timely predicted and remedy actions may be implemented. Also, it should be taken into account that the overrun of critical limit values may be unacceptable for some regions and acceptable for other regions [14]. To compile limit values of the economic safety indicators, it is necessary to clearly understand national interests of the state. According to a longterm forecast of the socio-economic development of the Russian Federation up to 2030, key national interests of the state should be considered as follows:

1) ability of the economy to function in the expanded reproduction mode;

2) competitiveness of the state, business and person;

3) improvement of the well-being and quality of life of the population;

4) stability of the financial and banking system;

5) effective foreign trade structure; access of domestic products of the processing industry to the international market; maximum/ minimum permissible level of the domestic demand satisfaction through imports;

6) Russia's independence in strategically important scitech development areas;

7) common economic space maintenance;

8) creation of economic and legal conditions to exclude criminalization of the society;

9) justified share of the state control functions, which meets the criteria of efficient and socially-oriented economic development.

Within the framework of this study, the object of the analysis was the sustainability of the financial component of Russia's economic safety.

Under today's economic crisis and sanction imposition conditions, the Russian government is trying to take measures to prevent threats within the country itself.

Task assignment for the study is as follows [15]:

1) to obtain limit values of the financial component of Russia's economic safety indicators;

2) to define actual values of the financial component of Russia's economic safety indicators for 2013-2017; 
3) to develop a predictive model of values of the financial component of Russia's economic safety indicators for 2018-2023;

4) to analyze trends based on predictions, and suggest optimization vectors.

Russian researchers in their publications classify 3 groups of limit values of the economic safety indicators: a production sector, a social sector and a financial sector (Table 1).

TABLE I. LIMIT VALUES OF THE ECONOMIC SAFETY INDICATORS

\begin{tabular}{|c|c|c|c|c|c|}
\hline $\begin{array}{l}\text { Production } \\
\text { sector }\end{array}$ & $\begin{array}{l}\text { Limit } \\
\text { value }\end{array}$ & Social sector & $\begin{array}{l}\text { Limit } \\
\text { value }\end{array}$ & $\begin{array}{l}\text { Financial } \\
\text { sector }\end{array}$ & $\begin{array}{l}\text { Limit } \\
\text { value }\end{array}$ \\
\hline $\begin{array}{l}\text { 1. GDP as a } \\
\text { whole, of } \\
\text { the average } \\
\text { for G7 }\end{array}$ & $75 \%$ & $\begin{array}{l}\text { 1. Average ratio } \\
\text { of the } \\
\text { population's } \\
\text { cash incomes to } \\
\text { the minimum } \\
\text { subsistence } \\
\text { income level }\end{array}$ & $7 \%$ & $\begin{array}{l}\text { 1. Internal } \\
\text { debt to GDP } \\
\text { ratio }\end{array}$ & $30 \%$ \\
\hline $\begin{array}{l}\text { 2. GDP per } \\
\text { capita, of } \\
\text { the world' } \\
\text { average }\end{array}$ & $\begin{array}{l}100 \\
\%\end{array}$ & $\begin{array}{l}\text { 2. Average life } \\
\text { expectancy }\end{array}$ & $\begin{array}{l}70 \\
\text { years }\end{array}$ & $\begin{array}{l}\text { 2. Foreign } \\
\text { debt to GDP } \\
\text { ratio }\end{array}$ & $25 \%$ \\
\hline \multirow[t]{3}{*}{$\begin{array}{l}\text { 3. GDP per } \\
\text { capita, of } \\
\text { the average } \\
\text { for G7 }\end{array}$} & \multirow{3}{*}{$50 \%$} & $\begin{array}{l}\text { 3. Gap between } \\
\text { the population's } \\
\text { incomes }\end{array}$ & $8 \%$ & $\begin{array}{l}\text { 3. Foreign } \\
\text { currency cash } \\
\text { size to the } \\
\text { RUB cash } \\
\text { size }\end{array}$ & $25 \%$ \\
\hline & & \multirow[t]{2}{*}{$\begin{array}{l}4 . \\
\text { Unemployment } \\
\text { rate }\end{array}$} & \multirow{2}{*}{$7 \%$} & $\begin{array}{l}4 . \quad \text { Budget } \\
\text { deficit to } \\
\text { GDP }\end{array}$ & $5 \%$ \\
\hline & & & & $\begin{array}{lr}5 . & \text { Money } \\
\text { supply } & \text { to } \\
\text { GDP }\end{array}$ & $50 \%$ \\
\hline
\end{tabular}

Source: authors' compilation based on [2]
The first group is the limit values in the production sector. Russia is a great country which must develop the production output with a minimal dependence on the outside world. The second group is the social sector. The third group includes the limit values of the financial sector. GDP (gross domestic product) that expresses the total scope of goods and services was assumed as the basis of indicators in the financial sector.

According to the forecasts of monitoring studies and taking into account the world experience and the Russian statistic data [2] (Table 2), the foreign national debt is likely to reach $33.4 \%$ of GDP by the end of 2018. Despite this, the share of the internal debt will not change significantly and will reach $8.9 \%$ of GDP. According to the forecasts for 2018, the budget surplus may exceed $0.3 \%$ of GDP. The money supply will be $41.4 \%$ of GDP.

Under financial instability conditions, subject to low monetization, the threat to the economic safety of the country tends to grow. Dynamic indices of the country's economy monetization level are closely linked with inflation. Because of the crisis, the inflation level in Russia has recently increased, and the incomes of the population, turnover and incomes of enterprises have dropped; this situation is deteriorating the monetization of the economy.

According to experts, the achievement of the optimum money supply-to-GDP ratio is explained by many economyspecific, which cannot be the same for all countries. To assess the economic safety of the Russian Federation, an economic profile, displaying the current status of the financial component, is recommended to be used, and the value of deviations from the limit values will serve as an indicator of the emergence of a potential threat to the loss of safety. An example of the economic profile of the financial component of the economic safety is shown in Fig. 1.

TABLE II. HISTORICAL DATA ON THE FINANCIAL COMPONENT OF THE RF ECONOMIC SAFETY IN 2011-2018

\begin{tabular}{|c|c|c|c|c|c|c|c|c|}
\hline Indicator & 2011 & 2012 & 2013 & 2014 & 2015 & 2016 & 2017 & 2018 (forecast) \\
\hline GDP, bln RUB & 60282.5 & 68163.9 & 73133.9 & 79199.7 & 83387.19 & 86148.57 & 92037.18 & 97691.4 \\
\hline RF foreign debt, bln USD & 488.5 & 538.9 & 636.4 & 728.9 & 597.3 & 518.5 & 511.7 & 518.9 \\
\hline $\begin{array}{l}\text { RF foreign debt, bln RUB (at } \\
\text { exchange rate of } 1: 62,85 \text { as of } \\
08.06 .18 \text { ) }\end{array}$ & 30702.23 & 33869.9 & 39997.7 & 45811.4 & 37540.31 & 32587.03 & 32160.16 & 32611.1 \\
\hline RF foreign debt, \% GDP & $50.9 \%$ & $49.7 \%$ & $54.7 \%$ & $57.8 \%$ & $45.0 \%$ & $37.8 \%$ & $34.9 \%$ & $33.4 \%$ \\
\hline RF internal debt, bln USD & 2940.39 & 4190.55 & 4977.9 & 5722.2 & 7241.2 & 7307.6 & 8003.46 & 8733.59 \\
\hline RF internal debt, \% GDP & $4.9 \%$ & $6.1 \%$ & $6.8 \%$ & $7.2 \%$ & $8.7 \%$ & $8.5 \%$ & $8.7 \%$ & $8.9 \%$ \\
\hline $\begin{array}{l}\text { RF budget deficit (-)/ surplus } \\
(+), \text { bln RUB }\end{array}$ & 442.04 & -39.45 & -322.98 & -334.70 & -1961.01 & -2956.41 & -1331.39 & 293.63 \\
\hline $\begin{array}{l}\text { Deficit (-)/ surplus share, } \% \text { in } \\
\text { GDP }\end{array}$ & $0.7 \%$ & $-0.1 \%$ & $-0.4 \%$ & $-0.4 \%$ & $-2.4 \%$ & $-3.4 \%$ & $-1.4 \%$ & $0.3 \%$ \\
\hline Money supply (M2), (+), bln RUB & 20011.90 & 24204.80 & 27164.60 & 31155.60 & 31615.70 & 35179.70 & 38417.90 & 40429.95 \\
\hline Money supply, \% in GDP & $33.2 \%$ & $35.5 \%$ & $37.1 \%$ & $39.3 \%$ & $37.9 \%$ & $40.8 \%$ & $41.7 \%$ & $41.4 \%$ \\
\hline
\end{tabular}


Limit value

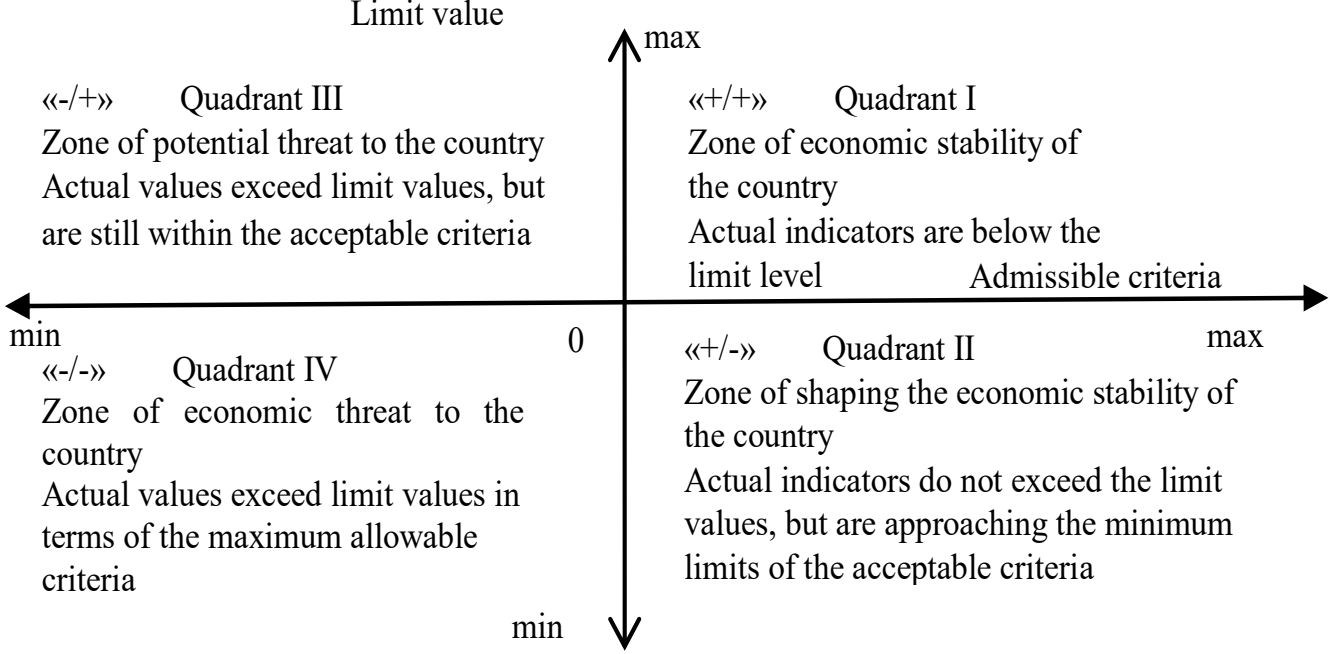

Source: authors' developments

Fig. 1. Economic profile of the financial component of the country's economic safety

\section{RESUlTS AND DisCUSSION}

The debt sustainability of the Russian economy can be analyzed, using indicators broadly applicable in the world practice. Financial stability indicators of the Russian economy in 2017 are specified in Table 3.

TABLE III. FINANCIAL STABILITY INDICATORS OF THE RUSSIAN ECONOMY IN 2017

\begin{tabular}{|c|c|c|c|c|}
\hline Indicator & 2017 & Criteria & $\begin{array}{l}\text { Limit } \\
\text { value }\end{array}$ & Quadrant \\
\hline $\begin{array}{c}\text { RF national debt, } \\
\% G D P\end{array}$ & $34.9 \%$ & $<50 \%$ & $25 \%$ & III \\
\hline $\begin{array}{c}\text { Share of expenses for } \\
\text { servicing the national debt } \\
\text { in the total federal budget } \\
\text { expenditures, } \%\end{array}$ & $7.1 \%$ & $<10 \%$ & $10 \%$ & I \\
\hline $\begin{array}{c}\text { Expenses for servicing the } \\
\text { national debt, bln RUB }\end{array}$ & 1162.4 & - & - & - \\
\hline $\begin{array}{c}\text { Federal budget expenses, } \\
\text { bln } R U B\end{array}$ & 16420.3 & - & - & - \\
\hline $\begin{array}{c}\text { Ratio of the RF national } \\
\text { debt to federal budget } \\
\text { revenues, \% }\end{array}$ & $213 \%$ & $<250 \%$ & $100 \%$ & III \\
\hline $\begin{array}{c}\text { Federal budget incomes, } \\
\text { bln } R U B\end{array}$ & 15088.9 & - & - & - \\
\hline $\begin{array}{c}\text { RF national debt, bln } \\
\text { RUB } \\
\end{array}$ & 32160.16 & - & - & - \\
\hline $\begin{array}{c}\text { Ratio of the RF national } \\
\text { foreign debt to the annual } \\
\text { scope of exported goods } \\
\text { and services, \% } \\
\end{array}$ & $145 \%$ & $<220 \%$ & $220 \%$ & I \\
\hline $\begin{array}{l}\text { Annual export of goods } \\
\text { and services, bln USD }\end{array}$ & 352.97 & - & - & - \\
\hline $\begin{array}{c}\text { Annual export of goods } \\
\text { and services, bln RUB (at } \\
\text { exchange rate of } 1: 62.85 \\
\text { as of } 08.06 .18 \text { ) }\end{array}$ & 22184.42 & - & - & - \\
\hline
\end{tabular}

Source: author's compilation based on $[6,7]$
Thus, as follows from the table, the indicators of the financial component of Russia's economic safety in 2017 stayed in Quadrants I \& III, which corresponds to the zone of economic stability and the potential threat zone to the state, respectively.

In 2017, the debt financial burden was low for the federal budget, which can affect the economic safety of the country. To more accurately identify threats and dangerous situations, a comprehensive assessment of the limit values of all indicators is required; meanwhile, all of these indicators must be within acceptable limits. Only this kind of analysis will allow the desired state safety level to be achieved.

Below in Table 4, the indicators of the financial stability of the Russian economy for 2018, compiled based on the forecasted values, are presented.

As follows from Table 4, the financial component of Russia's economic safety in 2018 is expected to remain at the same level: for the indicators, which are in Quadrant I 
TABLE IV. PREDICTED FINANCIAL STABILITY INDICATORS OF THE RUSSIAN ECONOMY IN 2018

\begin{tabular}{|l|c|c|c|c|}
\hline \multicolumn{1}{|c|}{ Indicator } & $\mathbf{2 0 1 8}$ & Criteria & $\begin{array}{c}\text { Limit } \\
\text { value }\end{array}$ & Quadrant \\
\hline $\begin{array}{l}\text { RF national debt, } \\
\% \text { GDP }\end{array}$ & $33.4 \%$ & $<50 \%$ & $25 \%$ & $\mathrm{III}$ \\
\hline $\begin{array}{l}\text { Share of expenses for } \\
\text { servicing the national debt } \\
\text { in the total federal budget } \\
\text { expenditures, \% }\end{array}$ & $6.3 \%$ & $<10 \%$ & $10 \%$ & $\mathrm{I}$ \\
\hline $\begin{array}{l}\text { Expenses for servicing the } \\
\text { national debt, bln RUB }\end{array}$ & 991.3 & - & - & - \\
\hline $\begin{array}{l}\text { Federal budget expenses, } \\
\text { bln RUB }\end{array}$ & 15626.4 & - & - & - \\
\hline $\begin{array}{l}\text { Ratio of the RF national } \\
\text { debt to federal budget } \\
\text { revenues, \% }\end{array}$ & $204 \%$ & $<250 \%$ & $100 \%$ & $\mathrm{III}$ \\
\hline $\begin{array}{l}\text { Federal budget incomes, } \\
\text { bln RUB }\end{array}$ & 15973.8 & - & - & - \\
\hline RF national debt, bln RUB & 32611.1 & - & - & - \\
\hline $\begin{array}{l}\text { Ratio of the RF national } \\
\text { foreign debt to the annual } \\
\text { scope of exported goods } \\
\text { and services, \% }\end{array}$ & $116 \%$ & $<220 \%$ & $220 \%$ & $\mathrm{I}$ \\
\hline $\begin{array}{l}\text { Annual export of goods } \\
\text { and services, bln USD }\end{array}$ & 445.97 & - & - & - \\
\hline $\begin{array}{l}\text { Annual export of goods } \\
\text { and services, bln RUB (at } \\
\text { exchange rate of 1:62.85 } \\
\text { as of 08.06.18) }\end{array}$ & 28029.09 & - & - & - \\
\hline
\end{tabular}

Source: author's compilation based on $[3,4,5]$

This is a good sign, but for the indicators from the Quadrant III, this is a bad sign (potential threats require the development of effective programs for the state's financial policy optimization: it's necessary to achieve values, corresponding to the Quadrant I level).

\section{CONCLUSION}

Considering the above-mentioned information, it can be concluded that systemic and integrated approaches, defining the need for shaping and implementing the organizational and the economic mechanism for managing the economic safety strengthening process (both comprehensively and at the level of its individual components), shall be applied to effectively provide the economic safety of the state. At the same time, a systematic approach to appropriate mechanism development assumes that the management system must take into account all aspects of the state's activity, and the mechanism itself must incorporate clearly outlined elements, relevant operation schemes and associated interfaces, whereas the integrated approach assumes certain actions on creating an effective system for managing the process of the state's economic safety strengthening through the development of a set of measures to ensure its stable development by establishing favorable conditions, and to neutralize and eliminate external and internal threats.

At the same time, the system of indicators, being a flag of the economic safety status of the state, should be complete (cover all state activity areas as much as possible), comprehensive (include fast monitoring indicators detailed to a minimum possible level to allow full evaluation) and dynamic (commensurability of dynamic estimates in periods under review).

The proposed method for assessing the financial component of Russia's economic safety is an express-method, which, nevertheless, allows a quick identification of weak points of an integrated system: if the indicator moves towards to a worse quadrant of the economic profile, state programs to optimize indicators should be formulated; if the indicator moves to a better quadrant, maintaining and stabilization state programs should be developed to support the financial component of Russia's economic safety.

\section{References}

[1] Federal Law 'About the national security Strategy of the Russian Federation until 2020' №537 (2009). Available at: http:// www.consultant.ru/document/cons_doc_LAW_87685.

[2] E. Mityakov, S. Mityakov, "Comparative analysis of approaches to the calculation of the generalized index of economic security of Russia", Modern problems of science and education, 2014, № 3, pp.162-168.

[3] External debt of the Russian Federation (2015), Federal State Statistics service, Available at: http://www.gks.ru/bgd/regl/b15 11/IssWWW.exe.

[4] Macroeconomic financial statistics (2018). The Central Bank of the Russian Federation. Available at: http://www.cbr.ru/statistics/?PrtId=svs.

[5] Federal budget (2018). Russian Ministry of Finance. Available at: https://www.minfin.ru/ru/statistics/fedbud.

[6] Y. Nikonova, R. Vlasenko, "Analysis of the structure and dynamics of the Russian money supply”, Young scientist, 2016, №10, pp. 797-800.

[7] L. Goncharenko, S, Sybachin, S. Ionkin, "The state of the research complex of Russia as a fundamental basis for the transition to an innovative type of development of the national economy", National safety, nota bene, 2017, № 2, pp. 109-119.

[8] L. Goncharenko, S.Sybachin, M. Khachaturyan, E. Sharko, "Development of the Organizational and Economic Mechanism of Strategic Management of Economic Safety of Russia in the Conditions of Digital Economy", 2018 8th ESE International Conference on Sports, Health and Management (ESE-SHM 2018), June 11-13, 2018, Paris, France, doi:10.5729/1nms.2018.91.180.

[9] B. Fernando, T. Didier, Gross capital flows: Dynamics and crises, Journal of Monetary Economics, 2013, Vol. 60, Issue 1 (January). pp 113-133.

[10] O. Williamson, Transaction Cost Economics: An Introduction. 2007, №3. Available at: http://www.economicsejournal.org/economics/discussionpapers/2007-3.

[11] S. Becker, P. Egger, M. von Ehrlich, "Absorptive capacity and the growth and investment effects of regional transfers: A regression discontinuity design with heterogeneous treatment effects", American Economic, Economic Policy, 2013, No 5(4), pp. 29-77.

[12] M. Solovyov, L.I. Koshkin, A.A. Sviryna, "Public property management: methodology, experience, innovations", Rostov-on-Don, Fenix, 2014.

[13] A. Radygin, "Privatization in the modern world: theory, empirical, "new dimension" for Russia", Moscow: Publishing house "Delo", Russian Presidential Academy of National Economy and Public Administration, 2014.

[14] W. Reijers, F. O’Brolcháin, P. Haynes, "Governance in Blockchain Technologies \& Social Contract Theories", Ledger, 2016, vol. 1, pp.134-151.

[15] Organization for Economic Co-Operation and Development (OECD). Secretary-General's Report to Ministers 2017, OECD Publishing: Paris, France, 2017. 